\title{
Alternative Treatment Methods for Refractory Overactive Bladder
}

\author{
Refrakter Aşırı Aktif Mesane İçin Alternatif Tedavi Yöntemleri
}

\section{Okan Alkis (1), Bekir Aras (1), Mehmet Sevim (1)}

Department of Urology, Kutahya Health Science University Faculty of Medicine, Kutahya, Turkey

Cite as: Alkis O, Aras B, Sevim M. Alternative treatment methods for refractory overactive bladder. Grand J Urol 2021;1(1):26-9.

Submission date: 03 December 2020

Acceptance date: 09 December 2020

Online first: 05 January 2021

Publication date: 20 January 2021

Corresponding Author: Okan Alkis / Kutahya Health Science University Faculty of Medicine, Department of Urology, Kutahya, Turkey okanalks@hotmail.com ORCID: 0000-0001-6116-9588

\begin{abstract}
Overactive bladder is a serious condition that can significantly impair quality of life. Antimuscarinic agents are recommended as second-line therapy in patients who do not benefit from behavioral therapy. However, the therapeutic efficacy of antimuscarinic agents is limited. Alternative treatment methods to medical treatment have been developed due to its limited effectiveness and frequent side effects. Posterior tibial nerve stimulation (PTNS), transcutaneous tibial nerve stimulation (TTNS), sacral neuromodulation (SNM), intravesical Botulinum toxin-A (BoNT/A) are prominent among these minimally invasive treatment methods in refractory OAB. All these methods have been demonstrated to be effective in the literature. BoNT/A and SNM are more effective, but have been reported to cause more side effects. In refractory OAB, any of these methods can be applied by considering the medical condition and request of the patient.
\end{abstract}

Keywords: refractory overactive bladder, mimal invasive, treatment

Öz

Aşırı aktif mesane (AAM), yaşam kalitesini önemli ölçüde bozabilecek ciddi bir durumdur. AAM'de davranış tedavisinden fayda görmeyen hastalarda ikinci basamak tedavi yöntemi olarak önerilen antimuskarinik ajanların terapötik etkinliği sınırlıdır. Sınırlı etkinliği ve yüksek yan etkileri nedeniyle tıbbi tedaviye alternatif tedavi yöntemleri geliştirilmiştir. Dirençli AAM'de bu minimal invaziv tedavi yöntemleri arasında posterior tibial sinir stimülasyonu (PTNS), transkutanöz tibial sinir stimülasyonu (TTNS), sakral nöromodülasyon (SNM), intravezikal Botulinum toksin-A (BoNT/A) öne çıkmaktadır. Tüm bu yöntemlerin literatürde etkili olduğu gösterilmiştir. BoNT/A ve SNM daha etkilidir, ancak daha fazla yan etkiye neden olduğu bildirilmiştir. Refrakter AAM'de hastanın durumu ve isteği göz önünde bulundurularak bu yöntemlerden herhangi biri uygulanabilir.

Anahtar Kelimeler: refrakter aşırı aktif mesane, minimal invaziv, tedavi 


\section{Introduction}

The term overactive bladder (OAB) is a symptomatological definition in which urgency is the main complaint and usually presents with symptoms accompanied by increased urination frequency and nocturnal urination and does not have any local pathological or metabolic reason to explain these symptoms [1]. The incidence of $\mathrm{OAB}$ ranges between $12-17 \%$ and increases with age [2]. In the literature, its incidence rates have ranged between $6.5 \%$ and $15.8 \%$ in men and $9.3-32.6 \%$ in women [3]. Each of the complaints included in the definition of OAB can seriously affect the quality of life.

Normal bladder contraction occurs when the muscarinic receptors in the detrusor muscle are stimulated with acetylcholine. Although the pathogenesis of $\mathrm{OAB}$ is not fully explained; sensitization of afferent nerves, deactivation of inhibitory mechanisms, and the emergence of contractions similar to primitive voiding reflexes are shown as pathogenetic mechanisms. Another hypothesis is that the number of intercellular connections among detrusor myocytes increase and these cells are spontaneously stimulated [4]. In addition to the fact that the etiopathogenesis cannot be explained clearly and due to the intense relationship with the autonomic nervous system, undesirable systemic side effects are common in treatments applied [2]. Although many methods are used in the treatment of $\mathrm{OAB}$, antimuscarinic agents constituted the most commonly used treatment method. In randomized placebo-controlled studies, it was observed that antimuscarinic agents provided an improvement in complaints at a rate of $50-60 \%$ [2]. Therefore, alternative treatment methods to medical treatment have been developed due to its limited effectiveness and highly frequent side effects.

\section{Posterior Tibial Nerve Stimulation (PTNS)}

Sacral S2-S4 segments, which provide neural control of the bladder, are the segments where the posterior tibial nerve, which is a peripheral nerve, also originates. Through this relationship, it is thought that the posterior tibial nerve is stimulated with electrical stimulation and provides neuromodulation of detrusor innervation. Although the mechanism of action of PTNS is not clear, it is thought that inhibition of preganglionic motor neurons of the bladder is achieved through afferent stimulation of the sacral cord [5]. In the literature, it was observed that improvement in symptoms of more than $50 \%$ in patients with refractory $\mathrm{OAB}$ whose complaints do not relieve using antimuscarinic agents and/or beta 3 agonists for at least 8 weeks [6-8]. Sherif et al. compared PTNS and botulinum toxin $\mathrm{A}(\mathrm{BoNT} / \mathrm{A})$ in patients with refractory OAB in their study and found that BoNT/A was more effective [9]. However, they stated that side effects are seen more frequently in BoNT/A. Also, in the review of Tubaro et al., BoNT/A was reported to be more effective than PTNS [10]. No significant difference was found in studies comparing the effectiveness of PTNS and TTNS [11,12].

\section{Transcutaneous Tibial Nerve Stimulation (TTNS)}

TTNS was introduced after PTNS, and found widespread use because it was not invasive and less painful for the patient. Besides, its effectiveness has been demonstrated in many studies in the literature [6,13-15]. The only difference between these procedures having the same mechanism of action is that PTNS uses direct electrical stimulation delivered through transdermal surface electrodes. The procedure has no side effects and the pain is very low. Also, TTNS should not require regular patient visits at clinics and usually is self-administered at home. Studies in the literature have reported that they have similar efficacies with PTNS in refractory OAB $[11,12]$.

\section{Sacral Neuromodulation (SNM)}

Sacral neuromodulation is a minimally invasive method involving the implantation of a programmable pulse generator that provides low amplitude electrical current delivered through the S3 foramen. Today, it is also used in interstitial cystitis, chronic pelvic pain syndrome, and neurogenic bladder in addition to refractory OAB [16-19]. Although it is a minimally invasive method, the disadvantages of the procedure include the difficulty of application, the possibility of infective complications, and the need for replacement dependent on the battery life. There are several studies in the literature comparing SNM with other minimally invasive treatment methods in refractory OAB. Richter et al. revealed that SNM is more effective than BoNT/A [20]. Amundsen et al. reported that there was no significant difference between efficacies of SNM and BoNT/A [21]. Again, Al-Azzawi et al. reported that there was no significant difference between efficacies of SNM and BoNT/A [22]. Bertapelle et al. stated that SNM is a more cost-effective method than BoNT/A [23].

\section{Intravesical Botulinum Toxin-A (BoNT/A)}

Intravesical Botulinum toxin-A application is the injection of the toxin of clostridium botulinum, a gram-negative anaerobic bacterium, into the detrusor muscle of the bladder [24]. BoNT/A acts by inhibiting neuromuscular acetylcholine release. BoNT/A inhibits both afferent and efferent pathways. This method of treatment is usually applied cystoscopically under anesthesia. It is generally applied as 100 units into the detrusor or suburothelial layer $[25,26]$. It has been shown in the literature that injection into the detrusor muscle is more effective than suburethral injection [27,28]. One of the most important advantages of the treatment is that its effect starts within a short time in the postoperative period. Its disadvantage is that its effectiveness last only 6-12 months. In the literature, it has been reported that a reduction in symptoms is achieved by more than $70 \%$ of the cases $[29,30]$. In this application, which has a high success rate, the complications are less but more than other minimally invasive methods. Major complications have been reported as respiratory depression and death. However, these are extremely rare. More frequently urinary infections and residual urine are seen. If residual urine is excessive, temporary clean intermittent catheterization is recommended [31]. In comparative studies in the literature, it has been reported that BoNT/A is more effective than PTNS $[10,11]$. It has also been reported that SNM and BoNT/A have similar efficiency $[21,22]$. However, Richter et al. found that SNM is more effective than BoNT/A [20]. 


\section{Conclusion}

Studies have demonstrated the significant benefits of all alternative minimally invasive treatments in the treatment of refractory OAB. Although BoNT/A and SNM have been associated with greater number of side effects, they are very effective treatment modalities. Also, there is no 3rd step treatment method recommended as the gold standard in current guidelines. In refractory $\mathrm{OAB}$, any of these methods can be applied by considering the medical condition and request of the patient.

Peer-review: Externally peer-reviewed.

Conflict of Interest: The authors declare that they have no conflict of interest.

Financial Disclosure: The authors have declared that they did not receive any financial support for the realization of this study.

\section{References}

[1] Abrams P, Cardozo L, Fall M, Griffiths D, Rosier P, Ulmsten $U$, et al. The standardisation of terminology of lower urinary tract function: Report from the standardisation sub-committee of the international continence society. Neurourol Urodyn 2002;21:167-78. https://doi.org/10.1002/nau.10052.

[2] Walsh P, Retik A, Kavoussi L, Vaughan E, Novick A, Wein A. Campbell-Walsh Urology. 10th ed. Philadelphia, PA: Elsevier; 2012.

[3] Zumrutbas AE, Bozkurt AI, Tas E, Acar CI, Alkis O, Coban $\mathrm{K}$, et al. Prevalence of lower urinary tract symptoms, overactive bladder and urinary incontinence in western Turkey: Results of a population-based survey. Int J Urol 2014;21:1027-33.

https://doi.org/10.1111/iju.12519.

[4] Gulur DM, Drake MJ. Management of overactive bladder. Nat Rev Urol 2010;7:572-82. https://doi.org/10.1038/nrurol.2010.147.

[5] Kabay SC, Yucel M, Kabay S. Acute Effect of Posterior Tibial Nerve Stimulation on Neurogenic Detrusor Overactivity in Patients with Multiple Sclerosis: Urodynamic Study. Urology 2008;71:641-5. https://doi.org/10.1016/j.urology.2007.11.135.

[6] Ammi M, Chautard D, Brassart E, Culty T, Azzouzi AR, Bigot P. Transcutaneous posterior tibial nerve stimulation: Evaluation of a therapeutic option in the management of anticholinergic refractory overactive bladder. Int Urogynecol J 2014;25:1065-9. https://doi.org/10.1007/s00192-014-2359-0.

[7] Leroux PA, Brassart E, Lebdai S, Azzouzi AR, Bigot P, Carrouget J. Transcutaneous tibial nerve stimulation: 2 years follow-up outcomes in the management of anticholinergic refractory overactive bladder. World J Urol 2018;36:1455-60.

https://doi.org/10.1007/s00345-018-2296-5.
[8] Rostaminia G, Chang C, Pincus JB, Sand PK, Goldberg RP. Predictors of successful percutaneous tibial nerve stimulation (PTNS) in the treatment of overactive bladder syndrome. Int Urogynecol J 2019;30:1735-45. https://doi.org/10.1007/s00192-018-3834-9.

[9] Sherif H, Khalil M, Omar R. Management of refractory idiopathic overactive bladder: Intradetrusor injection of botulinum toxin type A versus posterior tibial nerve stimulation. Can J Urol 2017;24:8838-46.

[10] Tubaro A, Puccini F, De Nunzio C. The management of overactive bladder: Percutaneous tibial nerve stimulation, sacral nerve stimulation, or botulinum toxin? Curr Opin Urol 2015;25:305-10. https://doi.org/10.1097/MOU.0000000000000180.

[11] Ramírez-García I, Blanco-Ratto L, Kauffmann S, CarraleroMartínez A, Sánchez E. Efficacy of transcutaneous stimulation of the posterior tibial nerve compared to percutaneous stimulation in idiopathic overactive bladder syndrome: Randomized control trial. Neurourol Urodyn 2019;38:261-8.

https://doi.org/10.1002/nau.23843.

[12] Martin-Garcia M, Crampton J. A single-blind, randomized controlled trial to evaluate the effectiveness of transcutaneous tibial nerve stimulation (TTNS) in Overactive Bladder symptoms in women responders to percutaneous tibial nerve stimulation (PTNS). Physiotherapy 2019;105:469-75. https://doi.org/10.1016/j.physio.2018.12.002.

[13] Booth J, Hagen S, McClurg D, Norton C, MacInnes C, Collins B, et al. A Feasibility Study of Transcutaneous Posterior Tibial Nerve Stimulation for Bladder and Bowel Dysfunction in Elderly Adults in Residential Care. J Am Med Dir Assoc 2013;14:270-4. https://doi.org/10.1016/j.jamda.2012.10.021.

[14] Manríquez V, Guzmán R, Naser M, Aguilera A, Narvaez S, Castro A, et al. Transcutaneous posterior tibial nerve stimulation versus extended release oxybutynin in overactive bladder patients. A prospective randomized trial. Eur J Obstet Gynecol Reprod Biol 2016;196:6-10. https://doi.org/10.1016/j.ejogrb.2015.09.020.

[15] Boudaoud N, Binet A, Line A, Chaouadi D, Jolly C, Francois Fiquet $\mathrm{C}$, et al. Management of refractory overactive bladder in children by transcutaneous posterior tibial nerve stimulation: A controlled study. J Pediatr Urol 2015;11:138.e1-138.e10. https://doi.org/10.1016/j.jpurol.2014.09.013.

[16] Steinberg AC, Oyama IA, Whitmore KE. Bilateral S3 Stimulator in Patients with Interstitial Cystitis. Urology 2007;69:441-3. https://doi.org/10.1016/j.urology.2006.10.032.

[17] Comiter C V. Sacral neuromodulation for the symptomatic treatment of refractory interstitial cystitis: A prospective study. J Urol 2003;169:1369-73. https://doi.org/10.1097/01.ju.0000053863.96967.5a. 
[18] Zabihi N, Mourtzinos A, Maher MG, Raz S, Rodríguez L V. Short-term results of bilateral S2 - S4 sacral neuromodulation for the treatment of refractory interstitial cystitis, painful baldder syndrome, and chronic pelvic pain. Int Urogynecol J Pelvic Floor Dysfunct 2008;19:553-7. https://doi.org/10.1007/s00192-007-0466-x.

[19] Lay AH, Das AK. The role of neuromodulation in patients with neurogenic overactive bladder. Curr Urol Rep 2012;13:343-7.

https://doi.org/10.1007/s11934-012-0272-y.

[20] Richter HE, Amundsen CL, Erickson SW, Jelovsek JE, Komesu Y, Chermansky C, et al. Characteristics Associated with Treatment Response and Satisfaction in Women Undergoing OnabotulinumtoxinA and Sacral Neuromodulation for Refractory Urgency Urinary Incontinence. J Urol 2017;198:890-6. https://doi.org/10.1016/j.juro.2017.04.103.

[21] Amundsen CL, Richter HE, Menefee SA, Komesu YM, Arya LA, Gregory WT, et al. Onabotulinumtoxin a vs sacral neuromodulation on refractory urgency urinary incontinence in women: A randomized clinical trial. JAMA 2016;316:1366-74. https://doi.org/10.1001/jama.2016.14617.

[22] Al-Azzawi IS, Al-Hindawi HT. A comparative study between sacral neuromodulation and intravesical botulinum toxin injection for patients with refractory overactive bladder. Arab J Urol 2020;18:88-93. https://doi.org/10.1080/2090598X.2020.1740391.

[23] Bertapelle MP, Vottero M, Popolo G Del, Mencarini M, Ostardo E, Spinelli M, et al. Sacral neuromodulation and Botulinum toxin A for refractory idiopathic overactive bladder: a cost-utility analysis in the perspective of Italian Healthcare System. World J Urol 2015;33:1109-17. https://doi.org/10.1007/s00345-014-1401-7.

[24] Unwala DJ, Barboglio P, Gousse AE. Repeated botulinum toxin injection for idiopathic overactive bladder: Will chemodenervation become a long-term solution? Curr Urol Rep 2007;8:419-24.

https://doi.org/10.1007/s11934-007-0041-5.
[25] Sahai A, Khan MS, Dasgupta P. Efficacy of Botulinum Toxin-A for Treating Idiopathic Detrusor Overactivity: Results From a Single Center, Randomized, Double-Blind, Placebo Controlled Trial. J Urol 2007;177:2231-6. https://doi.org/10.1016/j.juro.2007.01.130.

[26] Kessler TM, Danuser H, Schumacher M, Studer UE, Burkhard FC. Botulinum A toxin injections into the detrusor: An effective treatment in idiopathic and neurogenic detrusor overactivity? Neurourol Urodyn 2005;24:231-6. https://doi.org/10.1002/nau.20105.

[27] Kuo HC. Comparison of Effectiveness of Detrusor, Suburothelial and Bladder Base Injections of Botulinum Toxin A for Idiopathic Detrusor Overactivity. J Urol 2007;178:1359-63. https://doi.org/10.1016/j.juro.2007.05.136.

[28] Kuo HC. Bladder base/trigone injection is safe and as effective as bladder body injection of onabotulinumtoxinA for idiopathic detrusor overactivity refractory to antimuscarinics. Neurourol Urodyn 2011;30:1242-8. https://doi.org/10.1002/nau.21054.

[29] Brubaker L, Richter HE, Visco A, Mahajan S, Nygaard I, Braun TM, et al. Refractory Idiopathic Urge Urinary Incontinence and Botulinum A Injection. J Urol 2008;180:217-22. https://doi.org/10.1016/j.juro.2008.03.028.

[30] Tincello DG, Kenyon S, Abrams KR, Mayne C, ToozsHobson P, Taylor D, et al. Botulinum toxin A versus placebo for refractory detrusor overactivity in women: A randomised blinded placebo-controlled trial of 240 women (the RELAX Study). Eur Urol 2012;62:507-14. https://doi.org/10.1016/j.eururo.2011.12.056.

[31] Shepherd JP, Lowder JL, Leng WW, Smith KJ. InterStim sacral neuromodulation and botox botulinum-A toxin intradetrusor injections for refractory urge urinary incontinence: A decision analysis comparing outcomes including efficacy and complications. Female Pelvic Med Reconstr Surg 2011;17:199-203. https://doi.org/10.1097/SPV.0b013e318224e0d7. 